\title{
Cervicalis vertigo - létező kórkép vagy fikció?
}

\author{
Végh Ildikó dr. - Harmat Kinga dr. - Gerlinger Imre dr. \\ Pécsi Tudományegyetem, Általános Orvostudományi Kar, Klinikai Központ, \\ Fül-Orr-Gégészeti és Fej-, Nyaksebészeti Klinika, Pécs
}

\begin{abstract}
A cervicalis vertigo létezése napjainkban is vita tárgyát képezi. A kórkép alaptézise, hogy a nyak rendellenessége szédülést okoz. Maga az elnevezés nem pontos, hiszen a leírások alapján nem is igazi vertigóról van szó. A cervicalis vertigóra leginkább jellemző tünetek a nyaki fájdalom vagy diszkomfortérzet, az egyensúlyzavar vagy bizonytalanságérzet és a nyaki mozgáskorlátozottság. A kórkép eredete nem tisztázott egyértelmúen. A szakirodalom alapján négy, leginkább elfogadott hipotézisről beszélhetünk: neurovascularis, vascularis, proprioceptív elmélet és migrénasszociált cervicalis vertigo. Ezek közül a neurovascularis elmélet már idejétmúlt, létezése egyértelmúen megcáfolható. A cervicalis vertigo diagnózisának felállításakor minden esetben az alábbi nehézségekkel szembesülünk: nincs a kórképre specifikus diagnosztikai módszer, cervicalis vertigóra pathognomicus klinikai elemek nem állnak rendelkezésre, egyértelmú terápiás ajánlás nem létezik. A kórkép felállítása kizárásos elven alapul, azonban a pszichogén vertigo lehetősége további nehézségek elé állítja a klinikusokat. Kezelését illetően a manuálterápiás eljárások - vestibularis fejlesztőgyakorlatokkal kombinálva - tûnnek a leginkább célravezetőnek.
\end{abstract}

Orv Hetil. 2019; 160(25): 967-972.

Kulcsszavak: cervicalis, nyaki fájdalom, propriocepció, vascularis, vertigo

\section{Cervical vertigo - reality or fiction?}

The existence of cervical vertigo is still a question under debate. The basic hypothesis of the disease is that the abnormalities of the neck cause dizziness. The name itself is not accurate, as on the basis of the descriptions we cannot talk about true vertigo. The most common symptoms of cervical vertigo are cervical pain or discomfort, imbalance or dizziness and limitation of cervical movement. The origin of the disease is unclear. Based on the literature, there are four most accepted hypotheses: neurovascular, vascular, proprioceptive theory and migraine-associated cervicogenic vertigo. Of these, the neurovascular theory has already been discredited and its existence is clearly disproved. When diagnosing cervical vertigo, we always face the following difficulties: there is no diagnostic method specific to the disease, pathognomic clinical elements are unavailable, no clear therapeutic recommendation exists. The diagnosis of the disease requires the exclusion of alternatives, but the possibility of the existance of psychogenic vertigo causes further difficulties for the clinicians. Regarding the treatment, the combination of manual therapies and vestibular rehabilitation seems to be the most effective.

Keywords: cervical, neck pain, proprioception, vascular, vertigo

Végh I, Harmat K, Gerlinger I. [Cervical vertigo - reality or fiction?] Orv Hetil. 2019; 160(25): 967-972.

(Beérkezett: 2019. január 8.; elfogadva: 2019. február 9.)

A szédülés az egyik leggyakoribb panasz, mellyel a páciensek orvoshoz fordulnak. Súlyossága eltérő lehet, néhány esetben enyhe bizonytalanságérzet áll fenn, míg máskor akár a mindennapi életet jelentősen befolyásoló, az életminőséget rontó vagy akár az életet veszélyeztető állapotról beszélhetünk. A szédülés előfordulása az életkor növekedésével emelkedik.

A szédülés lehet perifériás vagy centrális eredetü. Emellett ismert, hogy egyes belgyógyászati kórképek - mint például a cardiovascularis betegségek, a diabetes - 
szintén szédüléssel járhatnak. Szédülés jelentkezhet gyógyszerek mellékhatásaként is, továbbá nem szabad elfeledkezni a pszichogén szédülésrôl sem.

A cervicalis vertigo, melynek alaptézise, hogy a nyak rendellenessége szédülést okoz, napjainkban is az egyik legvitatottabb klinikai entitás. A kórkép létezésének támogatói úgy gondolják, hogy ez az egyik leggyakoribb ok a szédülés hátterében. Nézetüket különféle tünetek, jelek, tézisek felállításával próbálják bizonyítani. A cervicalis vertigo ellenzői szerint ezek az elméletek pontatlanok, irrelevánsok. Általánosságban elmondható, hogy a cervicalis vertigo létezésével kapcsolatban két fontos tényt nem lehet figyelmen kívül hagyni: nincs olyan specifikus diagnosztikai módszer, mellyel a cervicalis vertigo egyértelmúen felállítható lenne, illetve a cervicalis vertigónak véleményezett esetek nagy részében a panaszok hátterében álló egyéb alternatíva is felmerül [1].

\section{Tünetek, nevezéktan}

A cervicalis vertigóra az alábbi tünetek jellemzők: nyaki fájdalom, illetve diszkomfortérzet, nyaki mozgáskorlátozottság, egyensúlyzavar, bizonytalanságérzet, a testtartás instabilitása, járásbizonytalanság. Alkalmanként tinnitus, vizuális zavarok is társulhatnak a kórképhez. A tünetek rendszerint epizodikusan jelentkeznek, percektől órákig tarthatnak. A nyak mozgása, fájdalma a tünetek rosszabbodásával jár együtt. Amikor a nyaki fájdalom enyhül, a tünetek súlyossága is csökken $[2,3]$.

A cervicalis vertigo kifejezés megalkotása Ryan és Cope [4] nevéhez füződik, akik 1955-ben írták le az általuk cervicalis vertigónak elnevezett kórképet, melynek hátterében károsodott szomatoszenzoros nyaki inputokat véleményeztek.

Furman és Cass [5] inkább a „cervicogen dizziness” kifejezést javasolta. A kórképet károsodott nyaki afferensek okozta egyensúlyi és térbeli tájékozódási zavarként jellemezték. Kijelentették, hogy a betegség nem vestibu- laris diszfunkcióból ered, így valódi vertigo nem is jöhet létre.

Yahia [6] az alábbiakat adta meg a cervicalis vertigo jellemzőiként: krónikus nyaki fájdalom, a nyak fordítását követő vertigo nystagmus nélkül, nyaki osteoarthritis és/vagy az intervertebralis discusok degeneratív elváltozásai.

Wrisley [7] elmélete szerint a cervicalis vertigo nyaki fájdalommal, egyensúlyzavarral, bizonytalanságérzettel járó állapot, melynek megállapításához a többi lehetséges vestibularis rendellenességet ki kell zárni.

\section{Patogenezis}

A cervicalis vertigo pontos patomechanizmusa nem ismert, ugyanakkor számos elmélet látott napvilágot a kórkép lehetséges etiológiájáról. A cervicalis vertigóval foglalkozó közlemények alapján az alábbi lehetséges patogenetikai magyarázatok a leginkább elfogadottak: neurovascularis hipotézis, vascularis hipotézis, proprioceptív elmélet, illetve a migrénasszociált cervicalis vertigo elmélete (1. táblázat).

A neurovascularis hipotézist másképpen Barré-Lieouszindrómának nevezzük első leíróik tiszteletére, akik 1928-ban publikálták elméletüket. Feltételezésük szerint a vertebralis artériákat körülvevő szimpatikus plexust a nyaki gerinc degeneratív elváltozásai, a nyak instabilitása mechanikailag irritálhatják, ami szimpatikusirritáció-reflexes vasoconstrictiót okoz a vertebrobasilaris rendszerben, illetve ischaemiát a belső fülben, ezáltal létrehozva a cervicalis vertigo tüneteit (vertigo, tinnitus, fejfájás, homályos látás, pupillatágulat, hányinger, hányás). Bár az elmélet kezdetben elfogadhatónak tûnt, a tudomány fejlődésével lehetővé váló későbbi állatkísérletek ezt megcáfolták, ugyanis bebizonyították, hogy a szimpatikus idegek elektromos stimulálása kevés hatással van az agyi véráramlásra, továbbá a szimpatikus denerváció nem okoz vasodilatatiót, sem pedig a szimpatikus irritáció vasoconstrictiót $[2,3,8]$.

1. táblázat |A cervicalis vertigo feltételezett patomechanizmusai és terápiája

\begin{tabular}{|c|c|c|c|}
\hline Hipotézis & Első leíró & Feltételezett patomechanizmus & Terápiás javaslat \\
\hline $\begin{array}{l}\text { Neurovascularis elmélet } \\
=\text { Barré-Lieou-szindróma }\end{array}$ & $\begin{array}{l}\text { Barré és Lieou } \\
1928\end{array}$ & $\begin{array}{l}\text { Az arteria vertebralisokat körülvevő } \\
\text { szimpatikus plexus mechanikai irritációja } \\
\rightarrow \text { reflexes vasoconstrictio a vertebrobasi- } \\
\text { laris rendszerben }\end{array}$ & - \\
\hline $\begin{array}{l}\text { Vascularis elmélet } \\
=\text { rotációs arteria vertebralis szindróma/ } \\
\text { „bow-bunter” szindróma }\end{array}$ & $\begin{array}{l}\text { Sorensen } \\
1978\end{array}$ & $\begin{array}{l}\text { Fejfordításkor az ellentétes oldali arteria } \\
\text { vertebralis kompressziója jön létre } \rightarrow \\
\text { vertebrobasilaris keringési zavar }\end{array}$ & $\begin{array}{l}\text { - Konzervatív (fejfordítás kerülése, } \\
\text { antikoagulálás) } \\
\text { - Sebészi (endovascularis módszer, } \\
\text { sztent, dekompresszió) }\end{array}$ \\
\hline $\begin{array}{l}\text { Proprioceptív elmélet } \\
=\text { szomatoszenzoros input hipotézis }\end{array}$ & $\begin{array}{l}\text { Ryan és Cope } \\
1955\end{array}$ & $\begin{array}{l}\text { A felső nyaki régió károsodott (sérült) } \\
\text { ízületi receptoraiból abnormális afferens } \\
\text { inputok jutnak a vestibularis magvakhoz }\end{array}$ & $\begin{array}{l}\text { - Gyógyszer (NSAID, izomlazítók, } \\
\text { betahisztin) } \\
\text { - Manuálterápia }\end{array}$ \\
\hline $\begin{array}{l}\text { A migrénasszociált cervicogen vertigo } \\
\text { elmélete }\end{array}$ & $\begin{array}{l}\text { Yacovino } \\
2013\end{array}$ & $\begin{array}{l}\text { A cervicalis-trigeminalis-vestibularis } \\
\text { útvonal aktivációja és kétirányú múködése }\end{array}$ & - \\
\hline
\end{tabular}

NSAID = nemszteroid gyulladáscsökkentő 


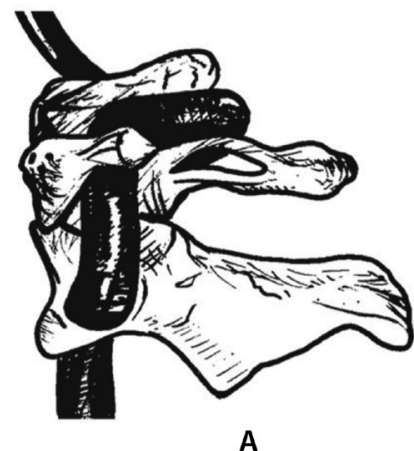

A

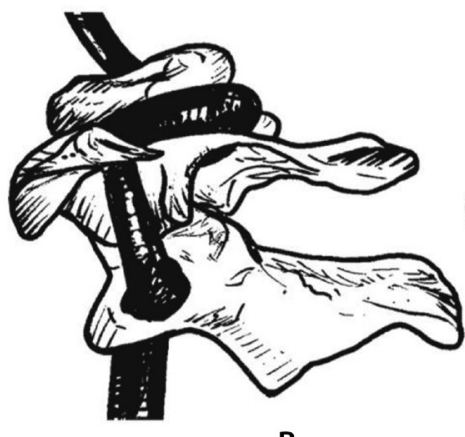

B

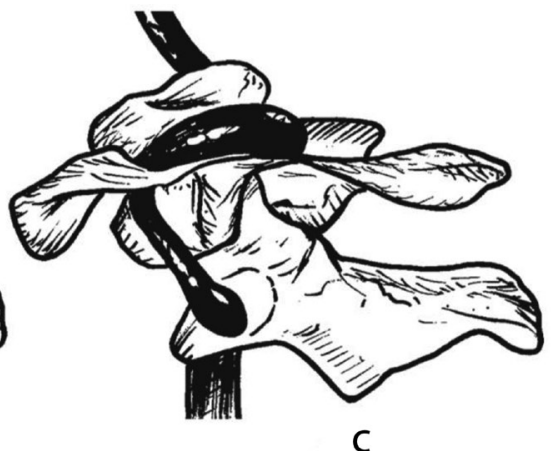

C

\begin{tabular}{l|l} 
1. ábra & $\begin{array}{l}\text { Rotációs arteria vertebralis szindróma } \\
\text { Az atlantoaxialis ízület mozgása lateralis irányból } \\
\text { A: neutrális helyzet; B: } 10^{\circ} \text {-os rotációkor; C: } 20^{\circ} \text {-os rotációkor } \\
\text { Minél nagyobb szögben történik az elmozdulás, annál jobban megnyúlik az arteria vertebralis, illetve annál inkább szúkül a lumene } \\
\text { Grafika: Kánya Péter }\end{array}$
\end{tabular}

Ismert még a vascularis elmélet mint „rotációs arteria vertebralis szindróma” vagy „bow-hunter szindróma” (1. ábra). Sorensen 1978-ban tette közzé elsőként ezt az elméletet esetbemutatás formájában. Egy pácienséről írt, akinél íjászkodást követően jelentkeztek a cervicalis vertigo tünetei. A hipotézis lényege, hogy fejfordítás során az egyik oldali arteria vertebralis kompressziója jön létre, jellemzően az atlantoaxialis ízület szintjén, aminek következtében, lényegében vertebrobasilaris insufficientia miatt, kialakulnak a jellegzetes tünetek. Maga az eset ritkaságnak számít, 2012-ig mintegy 40 rotációs arteria vertebralis szindrómás esetet publikáltak, melyek többségében a kompresszióért osteophyták (csontkinövések) voltak felelősek $[2,3,8,9]$.

A proprioceptív elméletet, vagy szomatoszenzoros input hipotézist 1955-ben publikálta Ryan és Cope [4], akik elméletük leírásával együtt a cervicalis vertigo elnevezést is megalkották. Elsőként feltételezték, hogy a felső nyaki régiók károsodott receptoraiból származó abnormális szomatoszenzoros információk következtében jönnek létre a típusos tünetek. Brandt és Bronstein [10] késóbb leírta, hogy a megváltozott felső cervicalis szomatoszenzoros inputok, melyek nyaki fájdalommal járnak együtt, kulcsfontosságú szerepet játszanak a cervicalis vertigo kialakulásában. Köztudott, hogy az egyensúly megtartása, a testhelyzet szabályozása komplex folyamat, melyben részt vesznek perifériás afferensek, a központi idegrendszer és effektor elemekként a vázizmok. A közülük bármelyik szinten fellépő legkisebb eltérés is egyensúlyzavart idézhet elő. A nyaki proprioceptorok legnagyobb számban a cervicalis gerinc felső ízületeiben találhatók. Mechanoreceptorok, melyek a helyzetérzékelés fontos elemei, a felső mély nyaki izmokban észlelhetők jelentős mennyiségben. Ezeknek a mechanoreceptoroknak a müködését megváltoztathatják direkt traumák, degeneratív gerincbetegségek, gyulladásos folyamatok, a nyaki izmok fáradása. Az elmélet értelmében a nyaki fájdalomból, mozgáskorlátozottságból kifolyólag károsodik a felső cervicalis szomatoszenzoros információ, továbbá gyulla- dásos mediátorok és metabolitok szabadulnak fel, melyek szenzitizálják az izomorsókat: hiperaktivitás jön létre, a nyaki szomatoszenzorok kisülése megváltozik, ami multiszenzoros „mismatch”-t, majd egyensúlyzavart okoz. Ez az elmélet magyarázatul szolgálhat az ostorcsapás-sérülést követően kialakuló szédülésre, illetve az idős betegek cervicalis vertigójára is. Az ostorcsapás-sérülést (2. ábra) elszenvedók leggyakoribb, tartósan fennálló panaszai a fejájás, vállfájdalom, nyaki diszkomfort, egyensúlyzavar, bizonytalanságérzés. A kialakuló, akár krónikusan is fennálló tünetek feltehetőleg a trauma következtében létrejövő károsodott nyaki propriocepció, illetve az ebből adódó megváltozott vizuális, vestibularis és proprioceptív afferenseket érintő téves megfeleltetés következményei. Az időskorúakra jellemző nyaki fájdalom és szédülés hátterében az alábbi folyamat állhat: a nyakat érintő osteoarthrosis megváltozott szomatoszenzoros jelet eredményez, ezzel egyidejűleg az életkor előrehaladtával mind a vestibularis, mind a proprioceptív rendszer múködése károsodik, így a hibás proprioceptív információ kijavítása, kompenzálása nem tud megtörténni $[1-3,8-10]$.

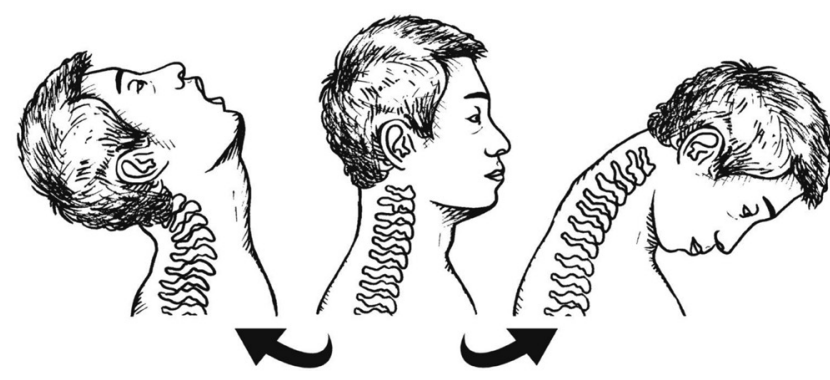

2. ábra Ostorcsapás-sérülés
Elsősorban közúti baleseteknél az ütközés következtében a fej
hirtelen tehetetlenül hátra-, illetve előrecsapódik, ami a nyaki
gerinc rándulását okozhatja
Grafika: Kánya Péter 
A legújabb elmélet 2013-ban látott napvilágot Yacovino [3] közleményében, aki hétköznapi klinikai megfigyeléseire hivatkozva feltételezi, hogy a cervicalis vertigo és a migrén szoros kapcsolatban van egymással. Köztudott, hogy a migrén gyakori kíséró tünete a szédülés, bizonytalanságérzés, nyaki fájdalom, illetve nyaki merevség. Ezen tünetek egy része - mint a szédülés, nyaki diszkomfort - a migrénes rohamok közti fejfájásmentes időszakban is fennállhat. A „migrénasszociált vertigo” kifejezés régóta ismert és elfogadott. Yacovino szerint a „cervicalis vertigo” és „migrénasszociált vertigo” tünetei gyakorlatilag megegyeznek, definíciójukban átfedés van, mely alapján javasolják egy új nómenklatúra, a „migrénasszociált cervicogen vertigo” bevezetését. Ezzel az elmélettel tulajdonképpen magyarázatot adnak arra, hogy miért fordulhat elő, hogy egyesek, akik nyaki fájdalommal küzdenek, szédülnek is, míg másoknál a nyaki fájdalmat szédülés nem kíséri. Úgy gondolják, a migrén lehet az összekötő kapocs a nyaki fájdalom és a cervicogen vertigo között. Az elméletük hátterében álló patogenezisre a cervicalis-trigeminalis-vestibularis útvonal kétirányú múködését feltételezik [2].

\section{Diagnosztika}

A cervicalis vertigo diagnosztizálása nem egyszerú feladat. Napjainkban sem létezik olyan specifikus diagnosztikus módszer, mellyel a kórkép egyértelmúen felállítható lenne. A páciensek szubjektív panaszaira, egyéb kórjelek hiányára, klinikai tapasztalatokra, tanulmányok és kutatások eredményeire kell elsősorban támaszkodnunk. A cervicalis vertigo diagnózis felállításának alapfeltétele a két fö tünet, a bizonytalanságérzet vagy szédülés és a nyaki fájdalom vagy nyaki diszkomfortérzet megléte. Abban az esetben, ha a szédülést nyaki fájdalom vagy kellemetlenségérzet nem kíséri, egyéb szédüléses kórképre kell gondolnunk [2].

Cervicalis vertigóra specifikus diagnosztikai tesztek kidolgozására több kísérlet is történt. Ezek közül egy példa a „cervicalis torziós teszt” [11]. A vizsgálat sötét helyiségben történik, ahol a páciens fejét 90 fokkal elfordítják az egyik, majd a másik irányba 15-15 másodperc erejéig. Mindeközben video-Frenzel-szemüveg segítségével rögzítik, hogy jelentkezik-e nystagmus a fej elfordításakor. Poszturográfiás vizsgálatokkal próbálták igazolni az ostorcsapás-sérülést elszenvedettek egyensúlyzavarát [12]. Abban az esetben, ha rotációs arteria vertebralis szindrómával állunk szemben, mágneses rezonanciás (MR-), illetve komputertomográfiás (CT-) angiográfia segítségével diagnosztizálhatjuk a kompresszió pontos helyét. Próbálkozások történtek az úgynevezett "arteria vertebralis teszt"-tel [13] (3. ábra), melynek lényege, hogy a fej és nyak egyidejü extenziója és rotációja okoz-e szédülést. A vizsgálat viszonylag egyszerúen és gyorsan kivitelezhető: a páciens hanyatt fekszik, a vizsgáló a nyaki gerinc passzív nyújtását, majd a fej passzív fordítását végzi; ezt követốen a fejet és nyakat neutrális

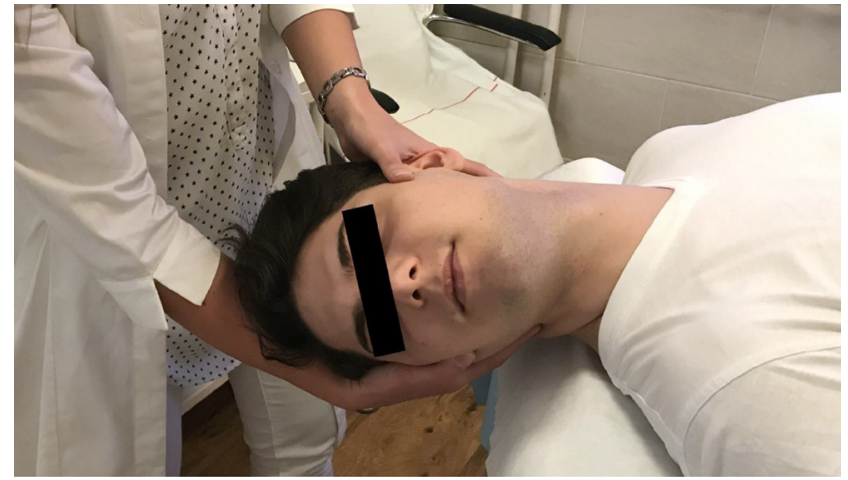

3. ábra Arteria vertebralis teszt
A páciens hanyatt fekszik, a vizsgáló a nyaki gerinc passzív nyúj-
tását, majd a fej passzív fordítását végzi, ezt követően a fejet és a
nyakat neutrális helyzetbe juttatja, majd az ellenoldalra megis-
métli a gyakorlatot. A páciens minden pozícióban 10 másodper-
cig mozdulatlan marad. (A gyakorlat végpozíciója tulajdonkép-
pen megegyezik a Dix-Hallpike-manóverével.) A vizsgálat során
a fejfordítással ellentétes oldalon az arteria vertebralis kompresz-
szió alá kerül, ami vertebrobasilaris múködési zavart, illetve en-
nek tüneteként szédülést provokálhat
Forrás: saját kép

helyzetbe juttatja, majd az ellenoldalra is megismétli a gyakorlatot. Minden pozícióban 10 másodpercig marad mozdulatlan a páciens. A gyakorlat végpozíciója tulajdonképpen megegyezik a Dix-Hallpike-manőverével. A vizsgálat során a fejfordítással ellentétes oldalon az arteria vertebralis kompresszió alá kerül, ami vertebrobasilaris múködési zavart, illetve ennek tüneteként szédülést provokálhat. Sajnos a teszt alacsony prediktív értékkel rendelkezik.

Összességében a cervicalis vertigo diagnosztikájáról elmondható, hogy az első körben minden esetben az otoneurológiai statust kell felállítani, melynek része a fizikális vizsgálat, illetve a rendelkezésre álló, lehetóleg minél szélesebb körú eszközös vizsgálatok (elektronystagmographia vagy videonystagmographia, forgatásos vizsgálatok, poszturográfia). Ha a legkisebb gyanú is felmerül centrális eredetre vonatkozóan, akkor neurológiai vizsgálat, esetleg koponya-képalkotó végzése szükséges. Tulajdonképpen a cervicalis vertigo megállapítása kizárásos elven alapul, amennyiben az egyéb szédüléses kórképek egyértelmúen elvethetők [14], illetve a tünetek alapján felmerül a nyaki eredet, akkor nyilváníthatunk egy szédüléssel járó betegséget cervicalis vertigónak. Nem szabad megfeledkezni azonban a pszichogén vertigo létezéséről sem, mely az utolsó kizárandó entitásként nehezíti a cervicalis vertigo diagnózisának felállítását.

\section{Terápia}

A cervicalis vertigo terápiája szintén kihívások elé állítja a klinikusokat, ugyanis nincs egyetlen, minden esetben használható, bizonyítottan hatékony, elfogadott ajánlás. Ideális helyzetben a kezelés során a vertigo hátterében álló okra kellene fókuszálni [15] (1. táblázat). 


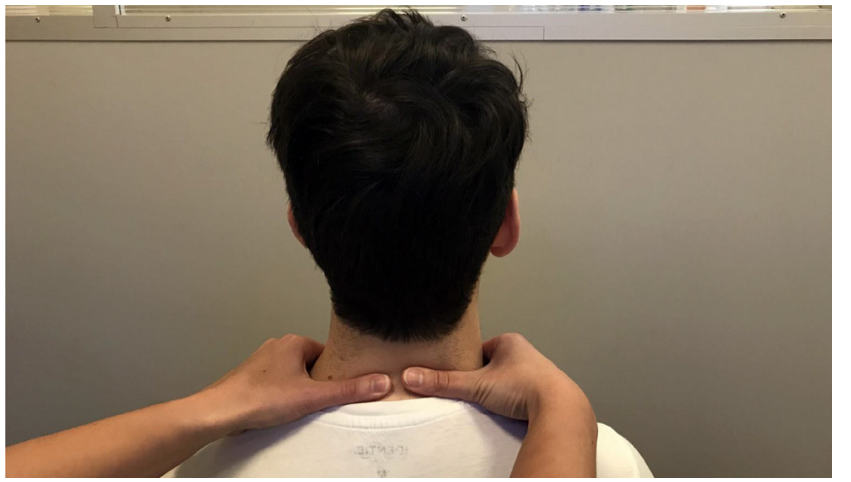

4. ábra

Manuálterápia

A manuálterápia alkalmazásával csökken a nyaki fájdalom és a fokozott izomtónus, javul a gerinc kis ízületeinek mobilitása, vagyis a nyaki gerinc normál proprioceptív és biomechanika funkciója visszatér

Forrás: saját kép

Proprioceptív diszfunkció okozta cervicalis vertigo esetében a terápia megegyezik a nyaki fájdalom terápiájával. Ebben az esetben gyógyszeres és nem gyógyszeres terápia jön szóba. A gyógyszerek közül nemszteroid gyulladáscsökkentőket, izomlazítókat, hányáscsillapítókat, nootropikumokat, betahisztinszármazékokat adhatunk betegeinknek. A nem gyógyszeres, vagyis fizioterápiás gyógymódok közül a manuálterápiás eljárásokat (4. ábra) kell előnyben részesíteni. Biztató eredményeket közöltek a Mulligan- és a Maitland-módszer alkalmazásáról [16]. A manuálterápia alkalmazásával csökken a nyaki fájdalom és a fokozott izomtónus, javul a gerinc kis ízületeinek mobilitása, vagyis a nyaki gerinc normál proprioceptív és biomechanikai funkciója visszatér. Többen javasolják vestibularis rehabilitációs gyakorlatok [17] végzését cervicalis vertigo esetén. Mivel az egyensúly megtartásában, illetve szabályozásában vestibularis, vizuális és nyaki szenzoros információk együttesen vesznek részt, melyek összehangolását a kisagy végzi, feltételezik, hogy vestibularis fejlesztőgyakorlatok által a vestibulocerebellaris rendszer sokkal jobban kompenzálhatja a megváltozott szenzoros nyaki afferenseket. Mindezt figyelembe véve többen javasolják a manuálterápiás módszerek és a vestibularis rehabilitációs gyakorlatok kombinált használatát cervicalis vertigóban [9].

Abban az esetben, amikor bizonyítottan rotációs arteria vertebralis szindróma áll a cervicalis vertigo hátterében, fizioterápia egyáltalán nem jön szóba, sőt veszélyes is lehet a betegre nézve. Itt a kezelés az egyszerú konzervatív módszerektől (az életminőség változtatása a fej fordításának kerülésével, antikoagulálás) a sebészi beavatkozásokig (endovascularis módszerek, sztent, dekompresszió) terjed [2, 3].

Spondylosis okozta cervicalis vertigo esetében anterior behatolásból végzett nyaki mútét, illetve a perkután lézeres porckorong-dekompresszió hatásos lehet. Peng és munkacsoportja [2] végzett egy tanulmányt, melyben összehasonlították, hogy azoknál a spondylosissal és cervicalis vertigóval küzdő betegeknél, akik konzervatív kezelésben részesültek, és akiknél anterior nyaki mütét történt, volt-e változás a szédülésben. Megfigyelésük alapján a mútéten átesetteknél 12 hónapos követési idő elteltével a szédülés mértéke jelentősen enyhült. Mindezek ellenére kijelenthetjük, hogy cervicalis vertigóban sebészi megoldás csak indokolt esetben jön szóba, csupán a szédülés, illetve az egyensúlyzavar csökkentése nem elég indok az operációra [9].

\section{Következtetés}

A cervicalis vertigo mint önálló klinikai entitás napjainkban is vita tárgyát képezi. Maga az elnevezés pontatlan, mivel forgó jellegű szédülés nem áll fenn, így célszerúbb lenne a szédülékenység (dizziness) szó használata.

A kórkép hátterében álló számos feltételezett kórfolyamat közül a proprioceptív elmélet, illetve a rotációs arteria vertebralis szindróma viszonylag elfogadható. A migrén és a cervicalis vertigo kapcsolatáról szóló öszszefüggés ígéretes lehet, a feltételezés igazolása azonban további pontosítást, illetve vizsgálatokat igényel.

A cervicalis vertigo diagnosztizálásával kapcsolatban elmondhatjuk, hogy a nagyon ritkán előforduló rotációs arteria vertebralis szindrómát leszámítva nincs olyan klinikai diagnosztikai módszer, mellyel egyértelmúen igazolhatnánk, hogy a nyaki eltérések szédülést provokálhatnak. Így továbbra is fennmarad egy olyan, szédüléssel küzdő betegcsoport, akiknél lehet, hogy cervicalis vertigo áll fenn, de jelen ismereteink szerint képtelenek vagyunk ezt bebizonyítani vagy egyértelműen megcáfolni.

A kezelés tekintetében a manuális és vestibularis fejlesztőgyakorlatok tűnnek a legészszerűbb terápiás stratégiáknak.

Mindezen ismeretek ellenére cervicalis vertigóról beszélve a mai napig az alábbi problémákkal szembesülünk: a cervicalis vertigo definíciója nem pontos és nem egységes, nincsenek epidemiológiai adataink, nincs specifikus diagnosztikai módszerünk, cervicalis vertigóra pathognomicus klinikai elemek nem ismertek, a kórkép patomechanizmusa nem egyértelmúen tisztázott, továbbá megfelelő diagnosztikai módszerek ellenére az esetek döntő részében a tünetek más szédüléses kórképre is jellemzőek lehetnek [3].

Brandt és Bronstein [10] összefoglaló véleménye szerint a cervicalis vertigo jelentőségéről és mechanizmusáról folyó vita inkább csak elméleti, mintsem gyakorlati jelentőségü.

Anyagi támogatás: A közlemény megírása és a kapcsolódó kutatómunka anyagi támogatásban nem részesült.

Szerzői munkamegosztás: V. I.: Irodalomkutatás, a közlemény megírása. H. K.: Irodalomkutatás. G. I.: A közle- 
mény tartalmi és nyelvhelyességi ellenőrzése. A cikk végleges változatát mindhárom szerző elolvasta és jóváhagyta.

Érdekeltségek: A szerzőknek nincsenek érdekeltségeik.

\section{Irodalom}

[1] Brandt T. Cervical vertigo: reality or fiction? Audiol Neurootol. 1996; 1: 187-196.

[2] Li Y, Peng B. Pathogenesis, diagnosis and treatment of cervical vertigo. Pain Physician 2015; 18: E583-E595.

[3] Yacovino DA, Hain TC. Clinical characteristics of cervicogenicrelated dizziness and vertigo. Semin Neurol. 2013; 33: 244-255.

[4] Ryan GM, Cope S. Cervical vertigo. Lancet 1955; 269: 13551358.

[5] Furman JM, Cass SP. Balance disorders: a case-study approach. F. A. Davis Company, Philadelphia, PA, 1996.

[6] Yahia A, Ghroubi S, Jribi S, et al. Chronic neck pain and vertigo: is a true balance disorder present? Ann Phys Rehabil Med. 2009; 52: 556-567.

[7] Wrisley DM, Sparto PJ, Whitney SL, et al. Cervicogenic dizziness: a review of diagnosis and treatment. J Orthop Sports Phys Ther. 2000; 30: 755-766.

[8] Peng B. Cervical vertigo: historical reviews and advances. World Neurosurg. 2018; 109: 347-350.

[9] Hain TC. Cervicogenic causes of vertigo. Curr Opin Neurol. 2015; 28: 69-73.

[10] Brandt T, Bronstein AM. Cervical vertigo. J Neurol Neurosurg Psychiatry 2001; 71: 8-12.
[11] L'Heureux-Lebeau B, Godbout A, Berbiche D, et al. Eveluation of paraclinical tests in the diagnosis of cervicogenic dizziness. Otol Neurotol. 2014; 35: 1858-1865.

[12] Bianco A, Pomara F, Petrucci M, et al. Postural stability in subjects with whiplash injury symptoms: results of a pilot study. Acta Otolaryngol. 2014; 134: 947-951.

[13] Cote P, Kreitz BG, Cassidy JD, et al. The validity of the extension-rotation test as a clinical screening procedure before neck manipulation: a secondary analysis. J Manipulative Physiol Ther. 1996; 19: 159-164.

[14] Tamás TL, Garai T, Király I, et al. Emergency diagnosis of the acute vestibular syndrome. [Az akut vestibularis szindróma sürgősségi diagnosztikájával szerzett tapasztalatok.] Orv Hetil. 2017; 158: 2029-2040. [Hungarian]

[15] Ferenc M, Hegyi M, Szirmai Á. Cervicogen vertigo? - Cervicogenic dizziness? [Nyaki szédülés? - Nyaki szédülékenység?] Gerincgyógy Szle. 2017; 6: 8-19. [Hungarian]

[16] Reid SA, Rivett DA, Katekar MG, et al. Comparison of Mulligan sustained natural apophyseal glides and Maitland mobilizations for treatment of cervicogenic dizziness: a randomized controlled trial. Phys Ther. 2014; 94: 466-476.

[17] Szirmai Á, Maihoub S, Tamás L. Efficacy of assisted balance training in chronic vestibular vertigo. [Az asszisztált egyensúlyi tréning hatékonysága krónikus vestibularis rendszeri szédülésben.] Orv Hetil. 2018; 159: 470-477. [Hungarian]

(Végh Ildikó dr., Pécs, Munkácsy M. u. 2., 7621 e-mail: veghildi0727@gmail.com)

\section{„Festina lente!" (Suetonius) (Lassan járj, tovább érsz!)}

A cikk a Creative Commons Attribution 4.0 International License (https://creativecommons.org/licenses/by/4.0/) feltételei szerint publikált Open Access közlemény, melynek szellemében a cikk bármilyen médiumban szabadon felhasználható, megosztható és újraközölhető, feltéve, hogy az eredeti szerző és a közlés helye, illetve a CC License linkje és az esetlegesen végrehajtott módositások feltüntetésre kerülnek. (SID_1) 